\title{
Pathogenesis of a Thai strain of white spot syndrome virus (WSSV) in juvenile, specific pathogen-free Litopenaeus vannamei
}

\author{
C. M. Escobedo-Bonilla ${ }^{1,2}$, M. Wille ${ }^{1}$, V. Alday Sanz ${ }^{3}$, P. Sorgeloos $^{1}$, M. B. Pensaert ${ }^{2}$, \\ H. J. Nauwynck ${ }^{2, *}$
}

${ }^{1}$ Laboratory of Aquaculture \& Artemia Reference Center, Faculty of Bioscience Engineering, Ghent University, Rozier 44, 9000 Ghent, Belgium

${ }^{2}$ Laboratory of Virology, Faculty of Veterinary Medicine, Ghent University, Salisburylaan 133, 9820 Merelbeke, Belgium

${ }^{3}$ INVE Technologies, Hoogveld 93, 9200 Dendermonde, Belgium

\begin{abstract}
White spot syndrome virus (WSSV) causes disease and mortality in cultured and wild shrimp. A standardized WSSV oral inoculation procedure was used in specific pathogen-free (SPF) Litopenaeus vannamei (also called Penaeus vannamei) to determine the primary sites of replication (portal of entry), to analyze the viral spread and to propose the cause of death. Shrimp were inoculated orally with a low $\left(10^{1.5}\right.$ shrimp infectious dose $50 \%$ endpoint [ $\left.\left.\mathrm{SID}_{50}\right]\right)$ or a high $\left(10^{4} \mathrm{SID}_{50}\right)$ dose. Per dose, 6 shrimp were collected at 0, 6, 12, 18, 24, 36, 48 and $60 \mathrm{~h}$ post inoculation (hpi). WSSVinfected cells were located in tissues by immunohistochemistry and in hemolymph by indirect immunofluorescence. Cell-free hemolymph was examined for WSSV DNA using 1-step PCR. Tissues and cell-free hemolymph were first positive at $18 \mathrm{hpi}$ (low dose) or at $12 \mathrm{hpi}$ (high dose). With the 2 doses, primary replication was found in cells of the foregut and gills. The antennal gland was an additional primary replication site at the high dose. WSSV-infected cells were found in the hemolymph starting from 36 hpi. At 60 hpi, the percentage of WSSV-infected cells was 36 for the epithelial cells of the foregut and 27 for the epithelial cells of the integument; the number of WSSV-infected cells per $\mathrm{mm}^{2}$ was 98 for the gills, 26 for the antennal gland, 78 for the hematopoietic tissue and 49 for the lymphoid organ. Areas of necrosis were observed in infected tissues starting from 48 hpi (low dose) or $36 \mathrm{hpi}$ (high dose). Since the foregut, gills, antennal gland and integument are essential for the maintenance of shrimp homeostasis, it is likely that WSSV infection leads to death due to their dysfunction
\end{abstract}

KEY WORDS: WSSV · Specific pathogen-free Litopenaeus vannamei · Pathogenesis · Oral inoculation · Immunohistochemistry · Indirect immunofluorescence $\cdot$ PCR

\section{INTRODUCTION}

White spot syndrome virus (WSSV) has caused serious economic losses to the shrimp farming industry in many countries in Asia, Latin America and the US (Lu et al. 1997, Chou et al. 1998, Wang et al. 1999, Hill 2002, Chapman et al. 2004). This has prompted the search for control measures and their evaluation through experimental inoculation tests. The development of standardized inoculation tests has been described in previous publications (Escobedo-Bonilla et al. 2005, 2006), in which we showed that such inoculation methods yield reproducible results.

In order to help formulate new control methods against disease it is important to have a better understanding of WSSV pathogenesis. At present, aspects of WSSV pathogenesis are known mainly from studies of naturally infected Asian shrimp species. Controversial results have stirred the debate about the sites of WSSV entry, primary replication and the mode of spread to distant target organs. Early juvenile (0.45 g) Penaeus monodon inoculated per os first showed WSSV- 
infected cells at $16 \mathrm{~h}$ post feeding in cells of the foregut, gills, integument and connective tissue of the hepatopancreas as determined by in situ hybridization (ISH) (Chang et al. 1996). However, in another study done with Marsupenaeus japonicus (also called Penaeus japonicus) epithelial cells in the midgut were suggested as the portal of WSSV entry per os (Di Leonardo et al. 2005). Likewise, the debate on the role of circulating hemocytes in the systemic spread of WSSV is rejected by some results obtained by ISH (van de Braak et al. 2002), while it is supported by others using immunofluorescence and transmission electron microscopy (Wang et al. 2002).

The main target organs of WSSV found in marine shrimp and many other crustaceans inoculated per os include the foregut, hindgut, gills, antennal gland, integument, gonads, muscle, nervous tissues, lymphoid organ, haematopoietic tissues, heart and hemocytes. All these organs are of ectodermal or mesodermal origin (Wongteerasupaya et al. 1995, Durand et al. 1996, Lo et al. 1997, Mohan et al. 1998, Sahul-Hameed et al. 1998). At present, no information is available on the pathogenesis of WSSV infection in the American shrimp Litopenaeus vannamei (= Penaeus vannamei).

In the present study, 2 different doses of a Thai WSSV stock were orally inoculated to juvenile specific pathogen-free (SPF) Litopenaeus vannamei using a standardized oral inoculation procedure previously described by Escobedo-Bonilla et al. (2006). A low inoculation dose resulted in a slower rate of disease progression than a high dose. The objectives were (1) to determine the sites of virus replication with emphasis on the portal of entry, (2) to analyze how WSSV spreads from the primary replication sites to other distant target organs, and (3) to search for the cause of death.

\section{MATERIALS AND METHODS}

Shrimp and experimental conditions. SPF Litopenaeus vannamei Kona strain were used. Shrimp (14.6 \pm $3.3 \mathrm{~g}$ mean body weight, $\mathrm{n}=102$ ) were acclimatized to a salinity of $15 \mathrm{~g} \mathrm{l}^{-1}$ and $27^{\circ} \mathrm{C}$ over $4 \mathrm{~d}$ at the facilities of the Laboratory of Aquaculture and Artemia Reference Center, Ghent University. Afterwards, they were transported to facilities of the Laboratory of Virology, Faculty of Veterinary Medicine, Ghent University, where 2 experiments were performed under standard biosafety conditions. In the first experiment, shrimp ( $\mathrm{n}=54)$ were inoculated with a low dose, in the second $(n=48)$ with a high dose. In each experiment, groups of 6 shrimp were kept in 501 glass aquaria equipped with water heaters (Visitherm, Aquarium Aystems), mechanical filters (Eheim Classic 2213) and continuous aeration. Aquaria were covered with glass and a plastic sheet to prevent virus dispersion by aerosol.

Virus. A Thai WSSV stock was used. WSSV from naturally infected Penaeus monodon was passaged once into crayfish and grown to high titers in SPF Litopennaeus vannamei. The virus stock was titrated in vivo by intramuscular and oral routes. The virus titer by oral route was $10^{5.6}$ shrimp infectious dose $50 \%$ endpoint $\left(\mathrm{SID}_{50} \mathrm{ml}^{-1}\right)$ as determined by indirect immunofluorescence (IIF) and 1-step PCR (EscobedoBonilla et al. 2005). A low $\left(10^{1.5} \mathrm{SID}_{50}\right)$ or a high $\left(10^{4.0} \mathrm{SID}_{50}\right)$ dose was made in phosphate-buffered saline (PBS), pH 7.4, volume $50 \mu \mathrm{l}$.

Oral inoculation procedure. Viral inoculation was performed by placing the shrimp with the ventral side up. A magnifying glass was used to locate the mouth. A long and flexible pipette tip (Biozym 790 004) was inserted beneath the labrum and anterior to the mandibles. The WSSV inoculum was delivered into the lumen of the foregut.

Time course. For each experiment, 6 shrimp were collected at $0,6,12,18,24,36,48$ and $60 \mathrm{~h}$ post inoculation (hpi), respectively. In addition, 6 control shrimp were inoculated with PBS only and collected at $72 \mathrm{hpi}$.

Sampling. Tissue processing: At each sampling time, the pereons of 3 shrimp were sectioned longitudinally, fixed with Davidson's solution for 24 to $48 \mathrm{~h}$, and placed in $50 \%$ ethanol for at least $24 \mathrm{~h}$ before paraffin embedding (Bell \& Lightner 1988, Lightner 1996). The pereons of the remaining shrimp were cross-sectioned at 3 different levels and processed for paraffin embedding.

The first cross-section was made at the anterior part of the pereon. Organs of the digestive system (foregut), excretory system (antennal gland), integument and internal organs (hematopoietic tissue) were located in this section. The second cross-section comprised the central part of the pereon in which organs of the digestive (foregut, anterior midgut cecum and hepatopancreas), respiratory (gills and branchial chamber), excretory (antennal gland) and nervous (ganglia and ventral cord) systems, integument and internal organs (lymphoid organ, gonads) were found. The third crosssection comprised the posterior part of the pereon where organs of the digestive (posterior part of the hepatopancreas and its junction with the midgut trunk) and respiratory (gills, branchial chamber) systems, integument and internal organs (heart and gonads) were located. Organs of the digestive tract in the tail were not analyzed.

Hemolymph collection: Hemolymph from each shrimp was also collected at each sampling time: shrimp were anaesthetized by placing them on ice. Then they were injected with $200 \mu \mathrm{l}$ of ice-cold Alsever's (AS) buffer, pH 7.0 (Rodríguez et al. 1995), in 
the anterior part of the pereon using a 24 -gauge needle (Terumo Europe), and $400 \mu$ l of hemolymph mixed with AS buffer was withdrawn. An aliquot (100 $\mu \mathrm{l})$ was diluted 1:10 in PBS and $70 \mu \mathrm{l}$ of the diluted hemolymph was placed into a cytospin (Cytospin 3, Shandon) fixed to a glass slide. The slides were centrifuged at $300 \times g$ for $4 \mathrm{~min}$ and immediately fixed at $-20^{\circ} \mathrm{C}$ in $100 \%$ methanol for $15 \mathrm{~min}$. The slides were air-dried and stored at $-20^{\circ} \mathrm{C}$ until IIF analysis was performed. Another aliquot $(100 \mu \mathrm{l})$ was spun down at $300 \times g$ for $5 \mathrm{~min}$ at $4^{\circ} \mathrm{C}$ to obtain cell-free hemolymph. This fraction was used to perform 1-step PCR for the early detection of WSSV DNA.

Analysis of WSSV infection. Immunohistochemistry (IHC): Paraffin-embedded tissue sections were cut at $4 \mu \mathrm{m}$ and placed onto Silane-coated slides (A3648, Sigma-Aldrich). Sections were deparaffinized and rehydrated. The endogenous peroxidase was blocked by incubating the slides for $30 \mathrm{~min}$ at room temperature in a solution of $1 \%$ sodium azide and $0.02 \%$ hydrogen peroxidase in Tris buffer $\mathrm{pH}, 7.4$. Sections were incubated for $1 \mathrm{~h}$ at $37^{\circ} \mathrm{C}$ with $2 \mathrm{mg}$ $\mathrm{ml}^{-1}$ of monoclonal antibody $8 \mathrm{~B} 7$ raised against WSSV envelope protein VP28 (Poulos et al. 2001). Sections were washed in Tris buffer ( $\mathrm{pH}$ 7.6) and incubated for $1 \mathrm{~h}$ at $37^{\circ} \mathrm{C}$ with a $1: 200$ dilution of biotinylated sheep anti-mouse IgG antibodies (RPN1001, Amersham Biosciences). Afterwards they were washed, incubated for $30 \mathrm{~min}$ at room temperature with 1:200 dilution of streptavidine-biotinylated horseradish peroxidase complex (RPN1051 Amersham Biosciences) and washed again. Color development was made with $0.01 \%$ of $3,3^{\prime}$-diaminobenzidine (D8001 Sigma-Aldrich). Sections were counterstained with Gill's hemaluin and washed in water, dehydrated and mounted. WSSV-infected cells were counted using light microscopy (Leica DM RBE) at a magnification of $400 \times$. Two different methods were used to quantify WSSV-infected cells in shrimp tissues: (1) WSSV-infected epithelial cells from the foregut and integument were counted in 5 randomly selected fields and expressed as percentage of the total number of cells. (2) WSSV-infected cells located in tissues/organs such as the antennal gland, hematopoietic tissue, lymphoid organ, heart, gonads and connective tissues were counted in 5 fields selected at random and expressed as the number of WSSV-infected cells $\mathrm{mm}^{-2}$. The quantitative method used depended on the tissues evaluated. For example, epithelial tissues are linearly arranged, so the proportion of WSSV-infected cells was determined as a percentage. In contrast, most of the internal organs are solid and composed of different cell types, so the proportion of WSSV-positive cells was determined as the number of infected cells $\mathrm{mm}^{-2}$.
Indirect immunofluorescence (IIF): Single or double stainings were made on cytospins with circulating hemocytes. Single stainings were made to detect WSSV-infected cells. The cytospins were washed for $5 \mathrm{~min}$ in PBS and incubated for $1 \mathrm{~h}$ at $37^{\circ} \mathrm{C}$ with $2 \mathrm{mg}$ $\mathrm{ml}^{-1}$ of monoclonal antibody 8B7 against VP28 (Poulos et al. 2001), washed twice for 5 min each in phosphatebuffered saline (PBS), incubated for $1 \mathrm{~h}$ at $37^{\circ} \mathrm{C}$ with $0.2 \mathrm{mg} \mathrm{ml}^{-1}$ of fluorescein isothiocyanate (FITC)labeled goat anti-mouse IgG antibodies (F-2761 Molecular Probes) and finally washed twice for 5 min each in PBS. Nuclear counter-stain of hemocytes was performed by incubating the slides for $10 \mathrm{~min}$ at room temperature with $0.01 \mathrm{mg} \mathrm{ml}^{-1}$ Bisbenzimide H 33342 solution (H1399 Molecular Probes). After 2 washings with PBS, cytospins were mounted. Double stainings were performed to characterize infected hemocytes. Here, a first incubation was made for $1 \mathrm{~h}$ at $37^{\circ} \mathrm{C}(1: 70$ dilution in PBS or $0.02 \mathrm{mg} \mathrm{ml}^{-1}$ solution) with hemocyte markers from Penaeus monodon (Winotaphan et al. 2005), or with wheat germ agglutinin (WGA) labeled with FITC (L4895 Sigma) (Martin et al. 2003). Cytospins were washed and incubated with $0.02 \mathrm{mg} \mathrm{ml}^{-1}$ goat anti-mouse IgG-FITC for $1 \mathrm{~h}$ at $37^{\circ} \mathrm{C}$. After washing, a second staining was made by incubating the slides with a 1:100 dilution of a polyclonal antiserum raised in rabbit against recombinant VP28 for $1 \mathrm{~h}$ at $37^{\circ} \mathrm{C}$. Slides were washed and incubated for $1 \mathrm{~h}$ at $37^{\circ} \mathrm{C}$ with $0.04 \mathrm{mg} \mathrm{ml}^{-1}$ of goat anti-rabbit IgG-Texas Red (T6391, Molecular Probes). Subsequently, slides were washed and counter-stained with Bisbenzimide H 33342 before being washed again and mounted. The analysis was performed using fluorescence microscopy (Leica DM RBE). Per shrimp, 500 hemocytes or hemocytes from 5 randomly selected fields (400×) were counted and the percentage of WSSV-infected cells determined. Slides without infected cells in this restricted number of cells counted were screened entirely.

One-step PCR: Cell-free hemolymph supernatant $(1 \mu l)$ was used to perform a 1-step PCR analysis. Each sample was added to a PCR tube containing $48 \mu \mathrm{l}$ of a PCR master mix $(1 \times$ PCR buffer [Eurogentec], $1.5 \mathrm{mM}$ $\mathrm{MgCl}_{2}, 0.3 \mathrm{mM}$ of each of the respective forward and reverse primers for WSSV or $\beta$-actin, $1.6 \mathrm{mM}$ dNTPs [Eurogentec], 1 U hot goldstar Taq polymerase [Eurogentec] in a total reaction volume of $50 \mu \mathrm{l}$ ). Primers F002 and R002 were used to amplify WSSV DNA, as well as Primers $F$ and R3 which amplified $\beta$-actin from shrimp and served as controls (Dhar et al. 2001). The expected amplicon for WSSV was $306 \mathrm{bp}$, while that for $\beta$-actin was $339 \mathrm{bp}$. A preheating step at $95^{\circ} \mathrm{C}$ for 10 min was followed by 35 cycles of denaturation $\left(94^{\circ} \mathrm{C}\right.$ for $\left.45 \mathrm{~s}\right)$, annealing $\left(55^{\circ} \mathrm{C}\right.$ for $\left.45 \mathrm{~s}\right)$ and extension $\left(72^{\circ} \mathrm{C}\right.$ for $\left.75 \mathrm{~s}\right)$. A final extension step $\left(72^{\circ} \mathrm{C}\right.$ 
for $5 \mathrm{~min}$ ) was made. PCR products were stored at $4{ }^{\circ} \mathrm{C}$. PCR products $(12 \mu \mathrm{l})$, negative (ultrapure water) and positive (DNA from a $10^{-2}$ dilution of WSSV stock) controls, as well as DNA markers (smart ladder, Eurogentec) were resolved on a $1.2 \%$ agarose gel in trisacetate-EDTA buffer. The gel was stained with ethidium bromide $\left(0.02 \mathrm{mg} \mathrm{ml}^{-1}\right)$ and DNA bands were visualized by UV transillumination.

Histopathology: Deparaffinized tissue sections were stained with hematoxilin-eosin-phloxine (Lightner 1996) and analyzed by light microscopy at a magnification of $400 \times$. Cellular changes and tissue damage were determined.

\section{RESULTS}

\section{WSSV pathogenesis with low dose $\left(10^{1.5}\right.$ SID $\left._{50}\right)$}

\section{Tissues}

The first WSSV-infected cells detected by IHC in tissues occurred at $18 \mathrm{hpi}$ in 1 of 6 shrimp. The primary sites of WSSV replication were epithelial cells in the foregut $(0.08 \%)$ (digestive system) and cells in the gills $\left(0.26\right.$ cells $\mathrm{mm}^{-2}$ ) (respiratory system) (Figs. 1 to 4$)$. At $24 \mathrm{hpi}, 5$ of 6 shrimp were WSSV-positive by IHC. In the digestive system, WSSV infection was observed in the epithelium $(2.7 \%)$ and connective tissues $\left(3.0\right.$ cells $\left.\mathrm{mm}^{-2}\right)$ of the foregut and connective tissues of organs in the midgut (anterior midgut cecum $=$ 2.8 cells $\mathrm{mm}^{-2}$ and hepatopancreas $=<0.1$ cells $\mathrm{mm}^{-2}$ ).
Epithelial cells in the midgut were refractory to WSSV (Fig. 1). Other organs infected with WSSV were the gills $\left(6.1\right.$ cells $\left.\mathrm{mm}^{-2}\right)$ and the integument of the gill chamber $(0.4 \%)$, the antennal gland $\left(2.0\right.$ cells $\left.\mathrm{mm}^{-2}\right)$ (excretory system) and internal organs associated with hemolymph circulation such as the lymphoid organ $\left(0.4\right.$ cells $\left.\mathrm{mm}^{-2}\right)$ and hematopoietic tissue $\left(0.3\right.$ cells $\left.\mathrm{mm}^{-2}\right)$ (Figs. 2 to 4$)$. In the heart, muscle and nervous system, only a few cells of the connective tissue were WSSV-positive. From 36 hpi until the end of the experiment (60 hpi), $100 \%$ of the shrimp collected were WSSV-positive by IHC. The highest number of infected cells was found in the gills $\left(81.9\right.$ cells $\left.\mathrm{mm}^{-2}\right)$, hematopoietic tissue (62.8 cells $\mathrm{mm}^{-2}$ ), epithelial cells $(34.1 \%)$ and connective tissue $\left(28.8\right.$ cells $\left.\mathrm{mm}^{-2}\right)$ of the foregut, lymphoid organ (28.7 cells $\mathrm{mm}^{-2}$ ), epithelial cells $(27.7 \%)$ and connective tissue (14.1 cells $\mathrm{mm}^{-2}$ ) of the integument and antennal gland (15 cells $\mathrm{mm}^{-2}$ ) (Figs. 1 to 4). Organs such as the heart, gonads, muscle, neuronal ganglia and nerve cord had only a few WSSV-positive cells located in connective tissues. In the gonads, no reproductive cells (eggs or sperm) were WSSV-positive by IHC.

\section{Hemolymph}

WSSV DNA was first detected by PCR at $18 \mathrm{hpi}$ in the cell-free hemolymph of 4 out of 5 shrimp (Fig. 5) and at 24 hpi in 5 of 6 shrimp. From 36 hpi until the end of the experiment (60 hpi), the hemolymph from all shrimp collected was WSSV DNA positive (not shown).
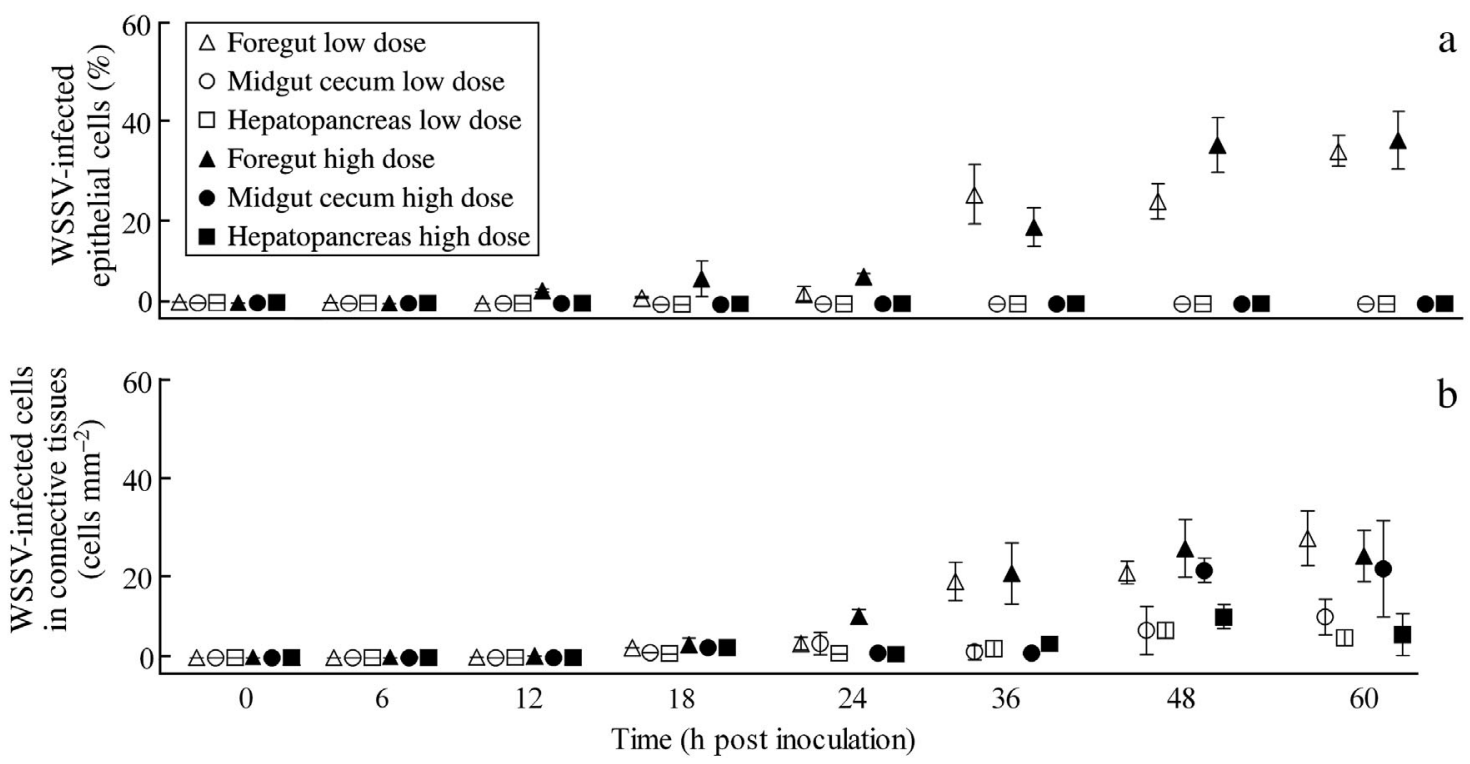

Fig. 1. Litopenaeus vannamei. Mean \pm SE proportion of WSSV-infected cells in (a) epithelium and (b) connective tissues of organs of digestive system in shrimp inoculated with low or high dose $;=6$ shrimp per time point 


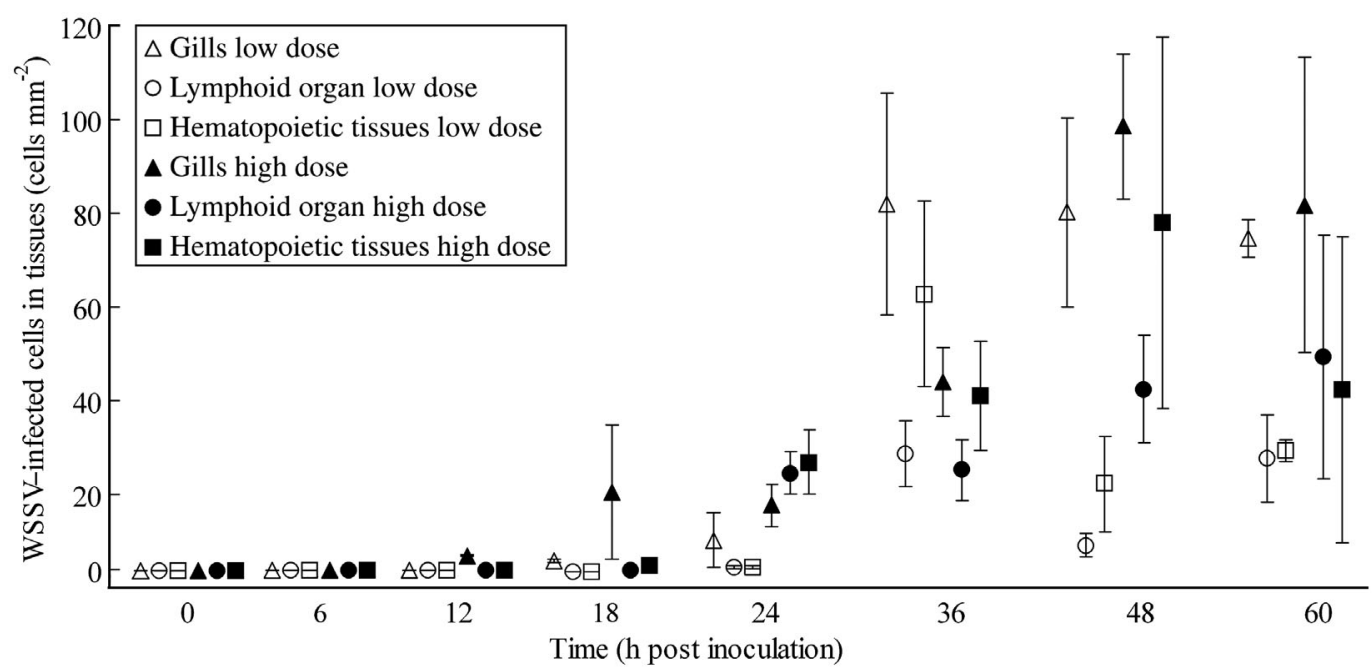

Fig. 2. Litopenaeus vannamei. Mean \pm SE proportion of WSSV-infected cells in gills and organs associated with circulatory system (hematopoietic tissues and lymphoid organ) of shrimp inoculated with low or high dose; $\mathrm{n}=6$ shrimp per time point

In contrast, the first WSSV-positive cells in the hemolymph were detected by IIF at 36 hpi in 3 of 6 shrimp; at 48 hpi in 1 of 6 shrimp, and at 60 hpi in 2 of 6 shrimp, respectively (Fig. 6).

\section{Histopathology}

WSSV-infected cells with hypertrophied nuclei and amphophilic inclusions were first observed at $36 \mathrm{hpi}$. Affected tissues were located in the digestive (foregut, anterior midgut cecum and hepatopancreas), respiratory (gills) and excretory (antennal gland) systems, integument and internal organs (hematopoietic tissue and lymphoid organ). Although hydropic degeneration was occasionally observed in cells of foregut, antennal gland, hematopoietic tissue and lymphoid organ, the structure of these organs remained intact. At $48 \mathrm{hpi}$, a higher proportion of hypertrophied cells showed hydropic degeneration, and some areas of focal necro-

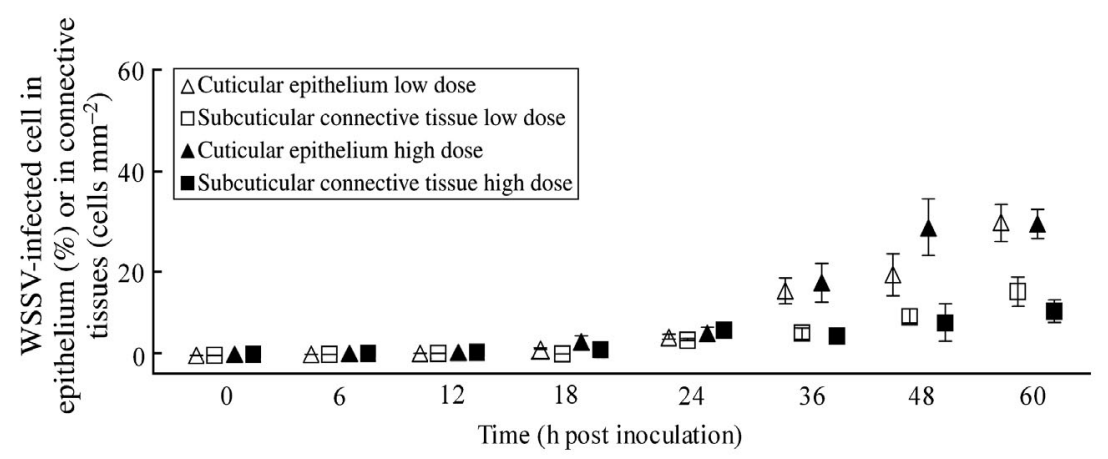

Fig. 3. Litopenaeus vannamei. Mean \pm SE proportion of WSSV-infected cells in cuticular epithelium and subcuticular connective tissues of shrimp inoculated with low or high dose; $\mathrm{n}=6$ shrimp per time point sis were observed in the foregut, gills, antennal gland, hematopoietic tissue and lymphoid organ. Occasionally, zones of erosion with hemocytic infiltration were observed in the foregut and anterior midgut cecum at 60 hpi. The structure of organs such as heart, gonads, muscle, neuronal ganglia and nerve cord remained intact throughout the experiment.

\section{WSSV pathogenesis with the high dose $\left(10^{4.0}\right.$ SID $\left._{50}\right)$}

\section{Tissues}

The first WSSV-infected cells were detected at 12 hpi by IHC in 4 of 5 shrimp. The primary sites of WSSV replication were the epithelial cells of the foregut $(0.3 \%)$ (digestive system), gills $\left(0.4\right.$ cells $\left.\mathrm{mm}^{-2}\right)$ (respiratory system) and antennal gland (0.4 cells $\mathrm{mm}^{-2}$ ) (excretory system) (Figs. 1 to 4 ). At 18 hpi, 6 of 6 shrimp were WSSV-positive. In the digestive system, WSSV-positive cells were observed in the epithelium $(6.6 \%)$ and connective tissue $\left(2.5\right.$ cells $\left.\mathrm{mm}^{-2}\right)$ of the foregut. In the anterior midgut cecum and hepatopancreas, WSSV-infected cells were only found in the connective tissues $\left(0.2\right.$ cells $\left.\mathrm{mm}^{-2}\right)$ (Figs. $1 \& 4$ ). At this time point, cells in the gills (18 cells $\mathrm{mm}^{-2}$ ), integument of the branchial chamber (1.6\%), lymphoid organ $\left(0.5\right.$ cells $\left.\mathrm{mm}^{-2}\right)$ and hematopoietic tissues (1.3 cells $\mathrm{mm}^{-2}$ ) were also WSSV-positive (Figs. 2 to 4). Organs such as the heart $\left(0.2\right.$ cells $\left.\mathrm{mm}^{-2}\right)$, gonads $\left(0.2\right.$ cells $\left.\mathrm{mm}^{-2}\right)$ and neuronal ganglia $\left(0.9\right.$ cells $\left.\mathrm{mm}^{-2}\right)$ showed WSSV-infected cells only in con- 

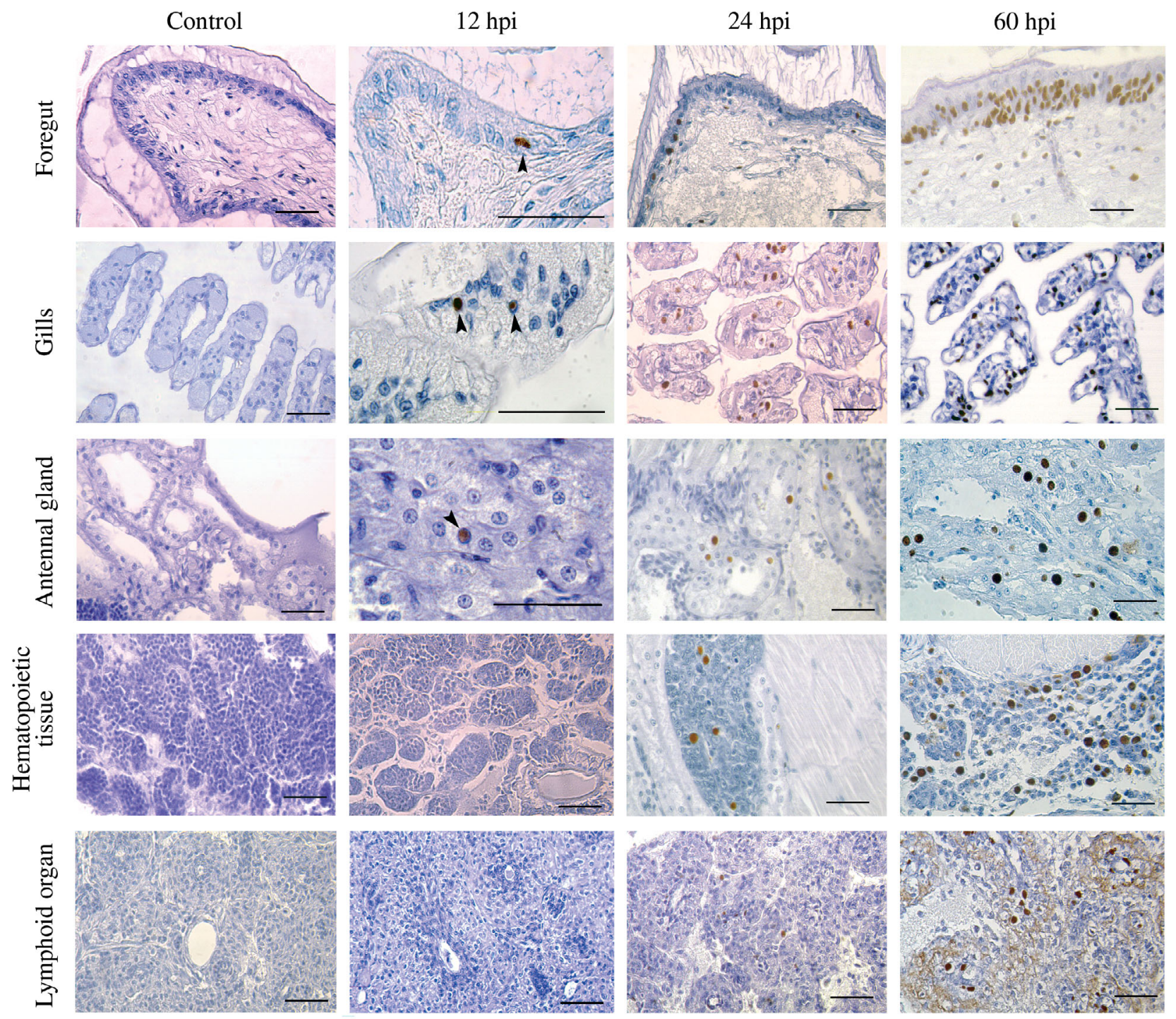

Fig. 4. Litopenaeus vannamei. Progression of WSSV infection in tissues of foregut, gills, antennal gland, hematopoietic tissues and lymphoid organ. Arrowheads indicate infected cells at $12 \mathrm{~h}$ post inoculation (hpi). Scale bars $=50 \mu \mathrm{m}$

nective tissues. Cardiac, neuronal and reproductive (eggs or sperm) cells were WSSV-negative. From $24 \mathrm{hpi}$ until the end of the experiment $(60 \mathrm{hpi})$ the mean number of WSSV-infected cells increased in tissues of the foregut, gills, antennal gland, integument and internal organs such as the hematopoietic tissues and the lymphoid organ (Figs. 1 to 4). The highest numbers of WSSV-infected cells were in the epithelial cells $(36.2 \%)$ and connective tissue $\left(23.1\right.$ cells $\left.\mathrm{mm}^{-2}\right)$ of the foregut, the epithelial cells $(27.5 \%)$ and connective tissue (10.1 cells $\left.\mathrm{mm}^{-2}\right)$ of the integument, and cells of the antennal gland $\left(26\right.$ cells $\left.\mathrm{mm}^{-2}\right)$. The organs most affected were associated with hemolymph circulation, i.e. the gills $\left(98.5\right.$ cells $\left.\mathrm{mm}^{-2}\right)$, hematopoietic tissue (78 cells $\mathrm{mm}^{-2}$ ) and lymphoid organ (49.4 cells $\mathrm{mm}^{-2}$ ).

\section{Hemolymph}

At $12 \mathrm{hpi}$, WSSV DNA was found by 1-step PCR in cell-free hemolymph of all the shrimp (Fig. 5). From this time until the end of the experiment, all collected shrimp were WSSV DNA-positive (data not shown). In contrast, the first WSSV-infected cells in the hemolymph were detected by IIF in 3 of 6 shrimp at $36 \mathrm{hpi}$ and in 4 of 6 shrimp at $48 \mathrm{hpi}$. At the end of the experiment (60 hpi), 3 of 6 shrimp had WSSV-positive cells in the hemolymph (Fig. 6). In the hemolymph, marker HC55 showed $53.5 \%$ of the circulating hemocytes to be semigranular and granular. Marker HC47d detected $34 \%$ of hemocytes as semigranular and hyaline, whereas monoclonal antibody HC201d recognized 


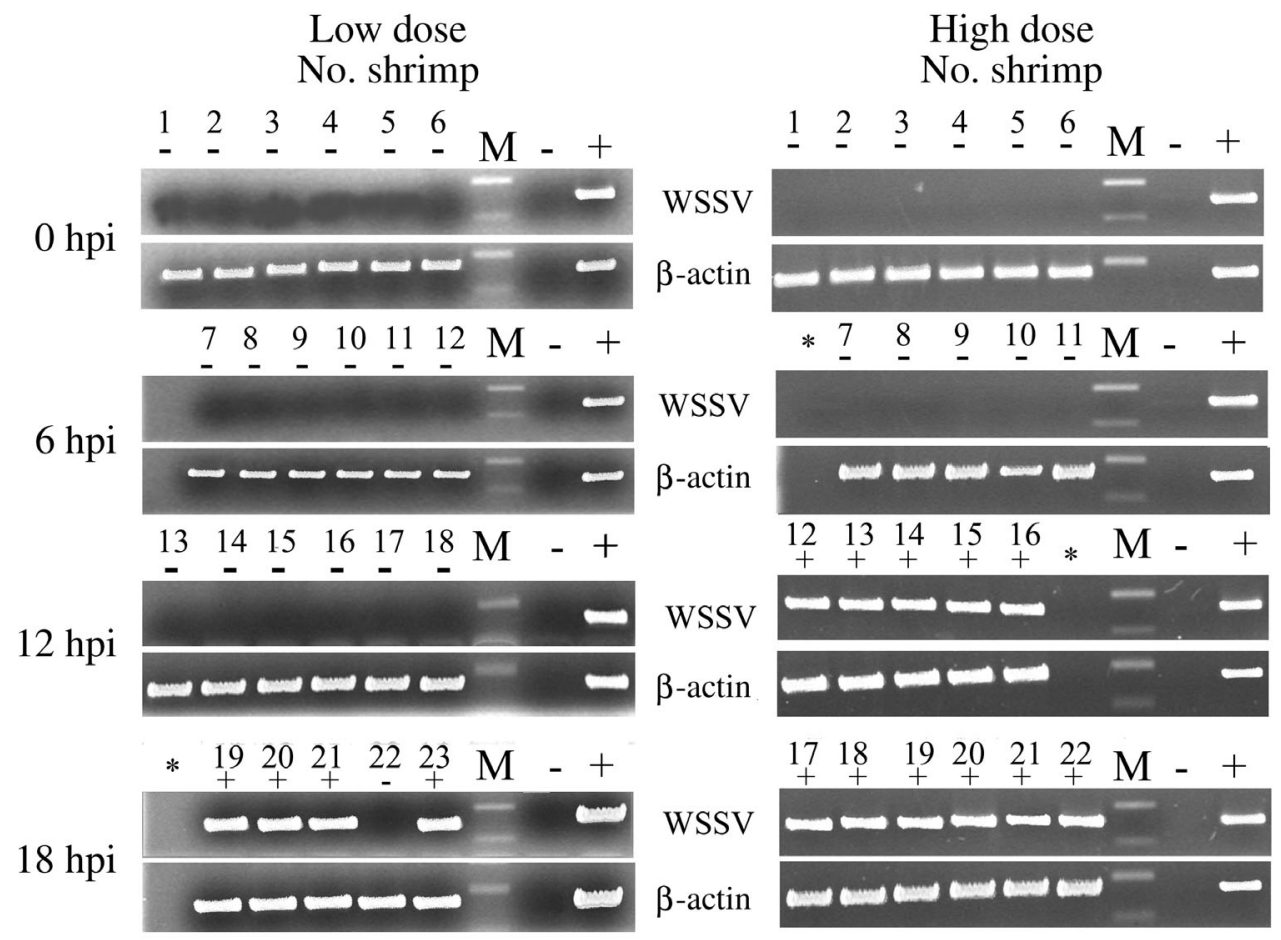

Fig. 5. Litopenaeus vannamei. WSSV DNA detection by 1-step PCR in cell-free hemolymph of shrimp inoculated with low or high dose. hpi: hours post inoculation; *: DNA samples not available; M: DNA weight marker; -: negative control; +: positive control

$28.1 \%$ of the hemocytes as hyaline and semigranular. The lectin WGA showed that $20.9 \%$ of the hemocytes were hyaline and semigranular while marker HC200 found $11.7 \%$ of the circulating hemocytes to be hyaline and semigranular. A proportion of $8.5 \%$ of the hemo- cytes were semigranular and granular according to marker HC249d, and 5.3\% of the circulating hemocytes were granular, as they reacted with monoclonal antibody HC114. None of these circulating hemocytes were found WSSV-positive by IIF using double staining.

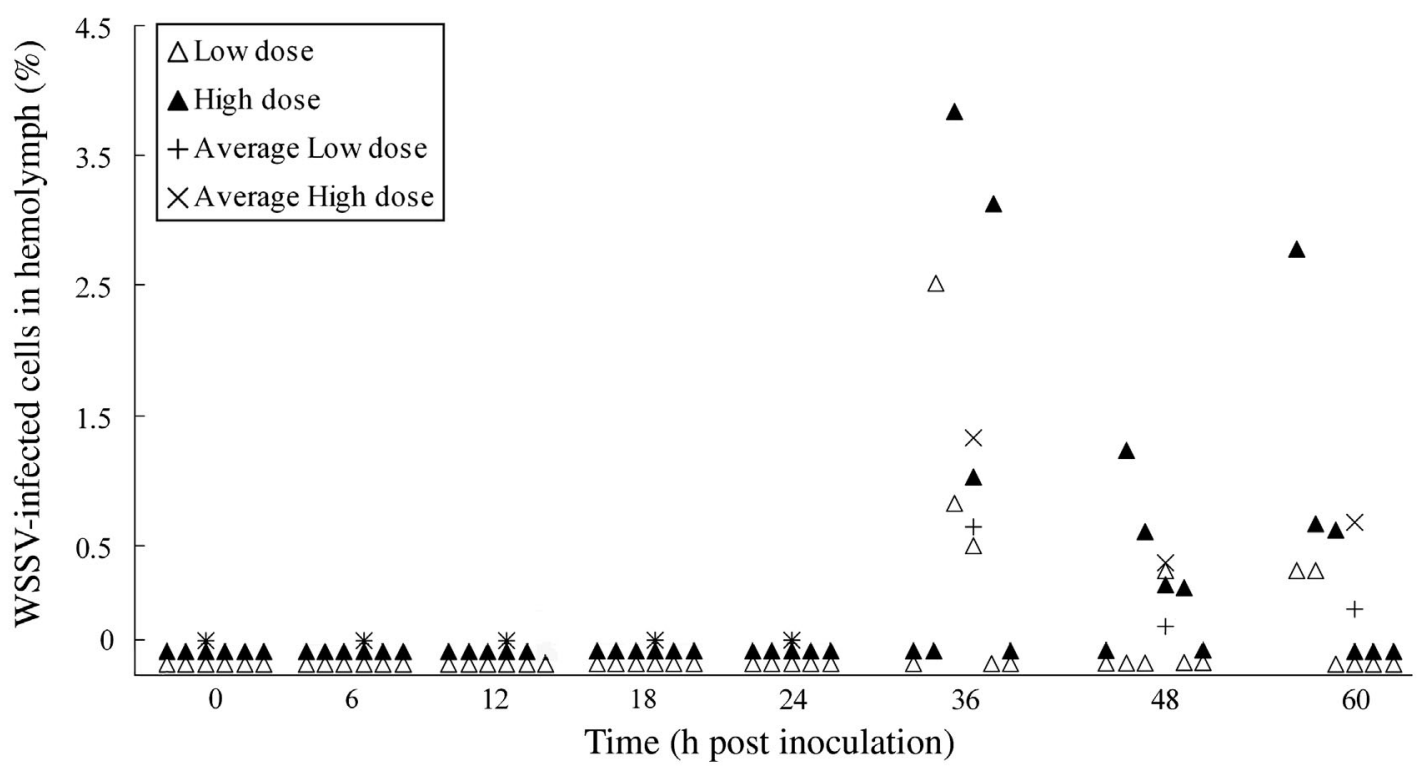

Fig. 6. Litopenaeus vannamei. Percentage of WSSV-infected cells in hemolymph of shrimp inoculated with low or high dose 
Histopathology

WSSV-infected cells with hypertrophied nuclei and amphophilic inclusions were first observed at $24 \mathrm{hpi}$. Affected organs were the foregut, gills, antennal gland, integument and internal organs such as the heart, hematopoietic tissue and the lymphoid organ. In the digestive system, only the anterior midgut cecum and hepatopancreas showed these intranuclear inclusions in connective tissues. Cells from muscle, gonads and neuronal ganglia did not show such cellular lesions. At 36 and $48 \mathrm{hpi}$, the number of damaged cells increased in the foregut, anterior midgut cecum, hepatopancreas, gills, antennal gland, integument and internal organs (hematopoietic tissue and lymphoid organ) and hydropic degeneration occurred in some cells. Small areas of erosion and focal necrosis appeared in the foregut epithelium (digestive system) and hemocytic infiltration occurred in the subjacent connective tissues. Areas of the integument, antennal gland and hematopoietic tissue occasionally showed some loss of structure, whereas the gills and internal organs such as the heart, lymphoid organ, gonads, neuronal ganglia and nerve cord were still intact. At $60 \mathrm{hpi}$, cytoplasmic detachment and focal necrosis was observed in the foregut epithelium. Some loss of structure was observed in the gills, antennal gland, integument and internal organs (hematopoietic tissue and the lymphoid organ). The structure of the heart, gonads, muscle and tissues of the nervous system appeared undamaged.

\section{DISCUSSION}

We have shown by oral inoculation that the portals of WSSV entry in Litopenaeus vannamei were epithelial cells of the foregut and cells in the gills at low and high doses, and also cells of the antennal gland at high dose. The foregut epithelium and cells in the gills were also described as primary sites of WSSV replication in early juvenile Penaeus monodon fed infected tissues per os (Chang et al. 1996). In contrast, another study on Marsupenaeus japonicus inoculated per os described epithelial cells of the midgut trunk as the primary WSSV replication sites (Di Leonardo et al. 2005). Shrimp species, the size/age of shrimp and the method of inoculation used may explain these differences.

After primary replication, WSSV spread to other target organs where the number of WSSV-infected cells increased, causing cellular and tissue damage. Early after inoculation, the proportion of WSSVpositive shrimp increased in a dose-dependent fashion. However, by the end of the experiments, the number of WSSV-infected cells in target organs was similar in shrimp inoculated with both low and high doses.
Although the foregut and gills are protected by a layer of cuticle, this could not prevent infection. The reason for this may be the lack of an epicuticle layer, the absence of calcification and/or the presence of numerous pore canals (Icely \& Nott 1992, Taylor \& Taylor 1992, Pratoomchat et al. 2002, Compère et al. 2004). Further, it cannot be excluded that during oral intubation, fissures were made in the cuticle of the foregut, resulting in free access of the virus to epithelial cells. The fact that cells in gills and/or antennal gland were also primary replication sites suggested that WSSV might have reached these organs by regurgitated or spilled inoculum. After primary replication (12 or $18 \mathrm{hpi}$, depending on the dose), newly produced WSSV would have been released from epithelial cells and crossed the basal membrane to reach the underlying connective tissues and associated hemal sinuses. By hemolymph circulation the virus would have reached other organs, so that WSSV-infected cells would be apparent in various organs throughout the body by 18 or 24 hpi (depending on the dose).

It appeared that early in infection, circulating hemocytes were refractory to WSSV infection and that WSSV spread in a cell-free form via hemolymph circulation. The absence of infected circulating hemocytes early in infection was also noticed in other WSSV pathogenesis studies in Penaeus monodon inoculated per os (van de Braak et al. 2002) or crayfish inoculated intramuscularly (Shi et al. 2000, 2005). We found a small proportion of shrimp with a few WSSV-infected cells in their hemolymph late during infection, but none of these cells were recognized by the hemocyte markers we used. Wang et al. (2002) also found WSSVpositive cells in the hemolymph of diseased Fenneropenaeus merguiensis ( $=$ P. merguiensis) by IIF and proposed that these were exclusively granular hemocytes. Since none of our tested hemocyte markers could bind to the infected cells we saw in Litopenaeus vannamei, they may have belonged to an unrecognized hemocyte type or, alternatively, may not have been hemocytes at all. Because of the time at which these WSSV-positive cells were first recorded (late post inoculation), it is possible that they were cells detached from infected tissues or disrupted during hemolymph extraction. Overall, our results suggest that hemocytes do not play an important role in the systemic spread of WSSV, at least in Litopenaeus vannamei.

Under culture conditions, many Asian and American shrimp species display white spots in their cuticle ( $T$. W. Flegel pers. comm.), but the exact mechanism of white spot formation is largely unknown. A WSSV infection may induce dysfunction of the integument, resulting in the accumulation of calcium salts within the cuticle (Wang et al. 1999). The present study has shown that the integument is one of the most affected 
organs in Litopenaeus vannamei although no white spots were observed. It is possible that under our experimental conditions the infection spread and killed the shrimp within $5 \mathrm{~d}$ post inoculation (dpi) (Escobedo-Bonilla et al. 2006), which is much faster than in culture conditions. Experiments performed with the penaeid species Trachypenaeus curvirostris and Metapenaeus ensis fed WSSV-infected tissues showed appearance of white spots as the disease slowly progressed (100\% mortality at $18 \mathrm{dpi}$ ) (Chang et al. 1998, Wang et al. 1998). In the field, the progression of disease before the acute stage may also be slow, and may explain the appearance of white spots in the cuticle.

Previous studies with Penaeus monodon brooders (Lo et al. 1997) or with P. monodon of undetermined age (Chang et al. 1998) have shown by ISH analysis that connective tissues and muscle sheaths around the ovary or testes/spermatophore are susceptible to WSSV infection. In the ovary of brooders, WSSV was detected in follicle cells and oogonia. A few developing oocytes were WSSV-positive. In testes, no reproductive cells were found infected with WSSV (Lo et al. 1997). In the present study, immature gonads of female or male juveniles showed WSSV-infected cells in the connective tissues only. In a few males, epithelial cells of the vas deferens were also infected, but the reproductive cells of both sexes were always WSSVnegative. These results suggest that the stage of gonad maturation may influence WSSV susceptibility of reproductive cells in the ovary. WSSV infection in gonads has been associated with poor spawning performance and low quality offspring (Lo et al. 1997), and it may also play a role in the vertical transmission of WSSV.

Gills, the foregut, integument and antennal gland were among the main WSSV target organs in Litopenaeus vannamei. The epithelial cells of these organs perform important functions such as gas exchange, transport and excretion of $\mathrm{CO}_{2}$ and ammonia, salt regulation and the control of the acid-base balance. These functions are critical for maintaining shrimp homeostasis, and all are involved in molting and growth (Ahearn et al. 1999, Wheatley 1999). Epithelial cells in these organs were increasingly damaged as WSSV infection progressed, which most probably led to dysfunction of these organs and death. Conversely, small numbers of WSSV-infected cells were found in the heart, neuronal ganglia, nerve cord and muscle, and the structure of these organs remained intact throughout the experiments.

In conclusion, a standardized oral inoculation procedure consistently showed the foregut and gills to be the primary sites of WSSV replication in Litopenaeus vannamei and that systemic spread occurred mainly via the cell-free form. Although hemocytic infiltration was observed, this reaction did not control virus replication in affected cells/tissues. The gills, foregut, integument and antennal gland were the main WSSV target organs. Because they perform critical functions for the maintenance of shrimp homeostasis, WSSV infection may lead to dysfunction of these organs and finally to death.

Acknowledgements. C.M.E.-B. received a scholarship (110056) from CONACyT (Mexico). This study was funded by a grant (BL/02/V02) from the Belgian Ministry of Science Policy. Thanks to Dr. P. Sithigorngul (Department of Biology, Faculty of Science, Srinakharinwirot University, Thailand) for providing the monoclonal antibodies against hemocytes; to Professor J. Vlak (Laboratory of Virology, Department of Plant Sciences, Wageningen University) for kindly providing a rabbit polyclonal antiserum against VP28; to Professor R. Ducatelle (Laboratory of Pathology, Faculty of Veterinary Medicine, Ghent University) for allowing us to work in the pathology laboratory and for his guidance in histopathology; and to Professor T. W. Flegel for his useful comments which improved the quality of this paper.

\section{LITERATURE CITED}

Ahearn GA, Duerr JM, Zhuang Z, Brown RJ, Aslamkhan A, Killebrew DA (1999) Ion transport processes of crustacean epithelial cells. Physiol Biochem Zool 72:1-18

Bell TA, Lightner DV (1988) A handbook of normal penaeid shrimp histology. World Aquaculture Society, Baton Rouge, LA

Chang PS, Lo CF, Wang YC, Kou GH (1996) Identification of white spot syndrome virus associated baculovirus (WSBV) target organs in the shrimp Penaeus monodon by in situ hybridization. Dis Aquat Org 27:131-139

Chang PS, Chen HC, Wang YC (1998) Detection of white spot syndrome associated baculovirus in experimentally infected wild shrimp, crabs and lobsters by in situ hybridization. Aquaculture 164:233-242

Chapman RW, Browdy CL, Savin S, Prior S, Wenner E (2004) Sampling and evaluation of white spot syndrome virus in commercially important Atlantic penaeid shrimp stocks. Dis Aquat Org 59:179-185

Chou HY, Huang CY, Lo CF, Kou GH (1998) Studies on transmission of white spot syndrome associated baculovirus (WSBV) in Penaeus monodon and P. japonicus via waterborne contact and oral ingestion. Aquaculture 164: 263-276

Compère P, Jeuniaux C, Goffinet G (2004) The integument: morphology and biochemistry. In: Forest J, Schram FR, von Vaupel Klein JC (eds) The Crustacea: revised and updated from the Traité de Zoologie, Vol 1. Koninklijke Brill, Leiden, p 59-144

Dhar AK, Roux MM, Klimpel KR (2001) Detection and quantification of infectious hypodermal and hematopoietic necrosis virus and white spot virus in shrimp using realtime quantitative PCR and SYBR green chemistry. J Clin Microbiol 39:2835-2845

Di Leonardo V, Bonnichon V, Roch P, Parrinello N, Bonami JR (2005) Comparative WSSV infection routes in the shrimp genera Marsupenaeus and Palaemon. J Fish Dis 28: 565-569 
Durand S, Lightner DV, Nunan LM, Redman RM, Mari J, Bonami JR (1996) Application of gene probes as diagnostic tools for white spot baculovirus (WSBV) of penaeid shrimp. Dis Aquat Org 27:59-66

Escobedo-Bonilla CM, Wille M, Alday-Sanz V, Sorgeloos P, Pensaert MB, Nauwynck HJ (2005) In vivo titration of white spot syndrome virus (WSSV) in specific pathogenfree Litopenaeus vannamei by intramuscular and oral routes. Dis Aquat Org 66:163-170

Escobedo-Bonilla CM, Audoorn L, Wille M, Alday-Sanz V, Sorgeloos P, Pensaert MB, Nauwynck HJ (2006) Standardized white spot syndrome virus (WSSV) inoculation procedures for intramuscular or oral routes. Dis Aquat Org 68: $181-188$

Hill B (2002) Keynote 2: National and international impacts of white spot disease of shrimp. Bull Eur Assoc Fish Pathol 22:58-65

Icely JD, Nott JA (1992) Digestion and absorption: digestive system and associated organs. In: Harrison FW, Humes AG (eds) Microscopic anatomy of invertebrates, Vol 10, Decapod Crustacea. Wiley-Liss, New York, p 147-201

Lightner DV (1996) A handbook of pathology and diagnostic procedures for diseases of penaeid shrimp. World Aquaculture Society, Baton Rouge, LA

Lo CF, Ho CH, Chen CH, Liu KF and 9 others (1997) Detection and tissue tropism of white spot syndrome baculovirus (WSBV) in captured brooders of Penaeus monodon with a special emphasis on reproductive organs. Dis Aquat Org 30:53-72

Lu Y, Tapay LM, Loh PC, Gose RB, Brock JA (1997) The pathogenicity of a baculo-like virus isolated from diseased penaeid shrimp obtained from China for cultured penaeid species in Hawaii. Aquac Int 5:277-282

Martin GG, Castro C, Moy N, Rubin N (2003) N-acetyl-D-glucosamine in crustacean hemocytes; possible functions and usefulness in hemocyte classification. Invertebr Biol 122: 265-270

Mohan CV, Shankar KM, Kulkarni S, Sudha PM (1998) Histopathology of cultured shrimp showing gross signs of yellow head syndrome and white spot syndrome during 1994 Indian epizootics. Dis Aquat Org 34:9-12

Poulos BT, Pantoja CR, Bradley-Dunlop D, Aguilar J, Lightner DV (2001) Development and application of monoclonal antibodies for the detection of white spot syndrome virus of penaeid shrimp. Dis Aquat Org 47:13-23

Pratoomchat B, Sawangwong $\mathrm{P}$, Guedes R, Reis MDL, Machado J (2002) Cuticle ultrastructure changes in the crab Scylla serrata over the molt cycle. J Exp Zool 293: $414-426$

Editorial responsibility: Timothy Flegel,

Bangkok, Thailand
Rodríguez J, Boulo V, Mialhe E, Bachère E (1995) Characterisation of shrimp haemocytes and plasma components by monoclonal antibodies. J Cell Sci 108:1043-1050

Sahul-Hameed AS, Anilkumar M, Raj MLS, Jayaraman K (1998) Studies on the pathogenicity of systemic ectodermal and mesodermal baculovirus and its detection in shrimp by immunological methods. Aquaculture 160: $31-45$

Shi Z, Huang C, Zhang J, Chen D, Bonami JR (2000) White spot syndrome virus (WSSV) experimental infection of the freshwater crayfish Cherax quadricarinatus. J Fish Dis 23: 285-288

Shi Z, Wang H, Zhang J, Xie Y, Li L, Chen X, Edgerton BF, Bonami JR (2005) Response of crayfish, Procambarus clarkii, haemocytes infected by white spot syndrome virus. J Fish Dis 28:151-156

Taylor HH, Taylor EW (1992) Gills and lungs: The exchange of gases and ions. In: Harrison FW, Humes AG (eds) Microscopic anatomy of invertebrates, Vol 10, Decapod Crustacea. Wiley-Liss, New York, p 203-293

van de Braak CBT, Botterblom MHA, Huisman EA, Rombout JHWM, van der Knaap WPW (2002) Preliminary study on the haemocyte response to white spot syndrome virus infection in black tiger shrimp Penaeus monodon. Dis Aquat Org 51:149-155

Wang YC, Lo CF, Chang PS, Kou GH (1998) Experimental infection of white spot baculovirus in some cultured and wild decapods in Taiwan. Aquaculture 164:221-231

Wang YG, Hassan MD, Shariff M, Zamri SM, Chen X (1999) Histopathology and cytopathology of white spot syndrome virus (WSSV) in cultured Penaeus monodon from peninsular Malaysia with emphasis on pathogenesis and the mechanism of white spot formation. Dis Aquat Org 39:1-11

Wang YT, Liu W, Seah JN, Lam CS, Xiang JH, Korzh V, Kwang J (2002) White spot syndrome virus (WSSV) infects specific hemocytes of the shrimp Penaeus merguiensis. Dis Aquat Org 52:249-259

Wheatley MG (1999) Calcium homeostasis in Crustacea: the evolving role of branchial, renal, digestive and hypodermal epithelia. J Exp Zool 283:620-640

Winotaphan P, Sithigorngul P, Muenpol O, Longyant S and 5 others (2005) Monoclonal antibodies specific to haemocytes of black tiger prawn Penaeus monodon. Fish Shellfish Immunol 18:189-198

Wongteerasupaya C, Vickers JE, Sriurairatana S, Nash GL and 6 others (1995) A non-occluded, systemic baculovirus that occurs in cells of ectodermal and mesodermal origin and causes high mortality in the black tiger prawn Penaeus monodon. Dis Aquat Org 21:69-77

Submitted: February 20, 2006; Accepted: September 20, 2006 Proofs received from author(s): December 18, 2006 